\title{
Источники скороспелости для селекции овса и ячменя в Северном Зауралье
}

Фомина М.Н. ${ }^{*}$, к.с.-х.н., в.н.С.; Иванова Ю.С., к.с.-х.н., н.с.; Пай О.А., н.с.; Брагин Н. А., н.с.; Белоусов С. А., м.н.с.

НИИСХ Северного Зауралья - филиал ФИЦ ТюмНЦ СО РАН, г. Тюмень, РФ. *e-mail: maria_f72@mail.ru

В условиях северной лесостепи Тюменской области в 2015-2019 г2. в коллекиионном питомнике было изучено 202 образиа ярового овса и 172 образиа ярового ячменя различного эколого-географического происхождения. Выявлена их селекционная ценность для регионов Зауралья и Сибири и выделены источники хозяйственно-ценных признаков для создания новых сортов овса и ячменя. В результате изучения коллекции определена группа образиов с коротким периодом вегетации, которые могут быть использованы в селекиии на скороспелость. Для создания скороспельх сортов овса могут быть использованы: Борот, Пенал, Скакор (Ленинградская обл.); Буланый (Московская область); Anak (Швеция); Ехро (Австрия) и другие; ячменя Первочелинник (Оренбургская область), Танай (Новосибирская область). Жулдус (Казахстан) и другие.

Ключевые слова: источники, исходный материал, образеи, скороспелость, селекиия.

\section{Sources of materiality for selection of oat and barley in the Northern Trans-Ural}

Fomina Maria Nikolaevna, Ivanova Julia Semenovna, Pay Olga Alekseevna, Bragin Nikolai Alexandrovich, Belousov Sergey Alexandrovich. Scientific Research Institute of Agriculture for Northern Trans-Ural Region - Branch of Tyumen Scientific Centre SB RAS, Moskowskiy, Tyumen district, Tyumen region, Russia.

In the conditions of the northern forest-steppe of the Tyumen region in 2015-2019. 202 samples of spring oats and 172 samples of spring barley of various ecological and geographical origin were studied in the collection nursery. Their breeding value for the regions of the Trans-Urals and Siberia was revealed and sources of economically valuable traits for creating new varieties of oats and barley were identified. As a result of studying the collection, a group of samples with a short growing season was identified that can be used in breeding for early maturity. To create precocious varieties of oats, the following can be used: Borot, Penal, Skakor (Leningrad Region); Bulany (Moscow region); Anak (Sweden); Expo (Austria) and others; barley - Pervotselinnik (Orenburg region), Tanay (Novosibirsk region). Zhuldus (Kazakhstan) and others.

Key words: sources, source material, sample, precocity, selection. 
Вегетационный период - одно из важнейших биологических свойств любой сельскохозяйственной культуры. Он является показателем пригодности сорта для возделывания в той или иной зоне и определяется как наследственными особенностями сорта, так и совокупностью внешних условий, в которых происходит их развитие $[1,2]$. Продолжительность периода вегетации напрямую связана с урожаем зерна [3], его качеством и посевными свойствами.

Создание скороспелых сортов актуально для большинства сельскохозяйственных зон Российской Федерации $[4,5]$. Вегетационный период у скороспелых образцов значительно короче по сравнению с позднеспелыми, однако они обладают меньшей вегетативной массой и потенциальной продуктивностью метелки [6].

Характерной особенностью погодных условий сибирских регионов (в т.ч. и Северного Зауралья) является короткий безморозный период. В связи с этим в числе первоочередных задач - проблема скороспелости, так как это одно из условий получения гарантированных урожаев [7].

Исследования проводились в 2015-2019 гг. на опытном поле НИИСХ Северного Зауралья - филиал ФИЦ ТюмНЦ СО РАН (северная лесостепь). Почва - серая лесная, тяжелосуглинистая. Для овса предшественник яровая пшеница, для ячменя - чистый пар.

Объектами исследования послужили 202 образца ярового овса и 172 образца ярового ячменя, полученных из ФИЦ «Всероссийский институт генетических ресурсов растений им. Н.И. Вавилова (ВИР). В качестве стандартов использовались сорта, возделываемые в регионе: Талисман (овес), Абалак (ячмень).

Метеорологические условия в северной лесостепи Тюменской области 2015-2019 гг. отличались нестабильностью по обеспеченности растений теплом и влагой.

Погода весенне-летнего периода в 2015 г. характеризовалась значительным выпадением осадков при высоких среднесуточных температурах в мае-июне и низких - в июле-августе $(Г T К=1,46)$. В 2016 г. май был теплым и сухим, июнь - в пределах нормы, жарким, с периодическим выпадение осадков, был июль. Сухой и жаркой погодой характеризовался август. ГТК за май-август составил 0,69 . Погодные условия вегетационного периода в 2017 г. отличались избыточным увлажнением и недостатком тепла в июне и июле. Незначительное количество осадков и высокие среднесуточные температуры в августе обеспечили своевременное созревание хлебов $(Г T К=1,48)$. Период вегетации 2018 года характеризовался как увлажненный $(\Gamma Т К=1,68)$. Сумма активных температур за вегетацию составила $1824^{\circ} \mathrm{C}$ (норма - 1844 $\left.{ }^{\circ} \mathrm{C}\right)$. В 2019 г. май был теплый и увлажненный $(\Gamma T К=1,04)$. Недостаток тепла и избыточное увлажнение отмечалось в июне $(Г Т К=1,74)$. Июль и август были теплыми и влажными (ГТК соответственно 1,81 и 1,51). Сумма активных 
температур за вегетацию составила $-1906^{\circ} \mathrm{C}$.

Оценка коллекционных образцов и фенологические наблюдения проводили согласно общепринятым методикам [7-9].

Статистическая обработка данных по методике полевого опыта [10] с использованием пакета прикладных программ Microsoft Excel и «Snedekor» [11].

Распределение сортов различного эколого-географического происхождения проводилось на основе изменчивости анализируемого признака в зависимости от метеорологических условий в годы исследований. Набор изучаемых коллекционных образцов сильно различался продолжительностью вегетационного периода. В целом за годы исследований период вегетации у образцов овса варьировал от 65 (Illinois 62-1535, США, 2015 г.) до 84 суток (местный, Румыния, 2015 г.); у образцов ячменя - от 63 (Танай, Новосибирская обл., 2018 г.) до 81 суток (Cerbinetta, Германия; Себастьян, Чехия и др., 2017 г.).

В коллекции овса доля среднеранних сортов составила 12,9 \%, среднеспелых $-55,4 \%$, среднепоздних - 32,2\%. В коллекции ячменя среднеранние образцы составили 20,9\%, среднеспелые - 48,3\%, среднепоздние - 30,8 \%.

В результате проведенных исследований выделена группа образцов овса с периодом вегетации 68 - 70 суток (при продолжительности вегетационного периода у стандарта Талисман 75 суток) и ячменя - периодом вегетации 66 - 68 суток (при продолжительности вегетационного периода у стандарта Абалак 70 суток). В качестве источников скороспелости у овса могут быть использованы: Борот, Пенал, Скакор (Ленинградская обл.); Буланый (Московская область); Anak (Швеция); Ехро (Австрия); Neklan (Чехия), Zvolen (Словакия), ряд образцов американского, китайского и австралийского происхождения; у ячменя - Первоцелинник (Оренбургская область), Танай (Новосибирская область). Жулдус (Казахстан) и другие (табл. 1).

Таблица 1 - Источники скороспелости овса и ячменя в условиях Северного Зауралья, 2015-2019 гг.

\begin{tabular}{|c|c|c|c|c|}
\hline \multirow{2}{*}{$\begin{array}{c}\text { № } \\
\text { каталога } \\
\text { ВИР }\end{array}$} & \multirow[b]{2}{*}{ Сорт } & \multirow[b]{2}{*}{ Страна-оригинатор } & \multicolumn{2}{|c|}{ Период вегетации, сут. } \\
\hline & & & Среднее & $\begin{array}{c}\text { Размах } \\
\text { варьирования }\end{array}$ \\
\hline 1 & 2 & 3 & 4 & 5 \\
\hline \multicolumn{5}{|c|}{ Овес яровой } \\
\hline & Талисман (St) & Тюменская обл. & 75 & $74-76$ \\
\hline 14858 & Борот & Ленинградская обл. & 68 & $68-69$ \\
\hline 15313 & Пенал & Ленинградская обл. & 69 & $66-72$ \\
\hline 15312 & Скакор & Ленинградская обл. & 70 & $67-72$ \\
\hline 15277 & Буланый & Московская обл. & 70 & $68-72$ \\
\hline 15237 & Anak & Швеция & 70 & $66-73$ \\
\hline 14936 & Neklan & Чехия & 68 & $67-69$ \\
\hline 15080 & Expo & Австрия & 70 & $69-70$ \\
\hline 15135 & Zvolen & Словакия & 69 & $66-72$ \\
\hline
\end{tabular}




\begin{tabular}{|c|c|c|c|c|}
\hline 1 & 2 & 3 & 4 & 5 \\
\hline 15307 & Ajay & США & 68 & $67-69$ \\
\hline 15306 & Y 201-150-8-19 & США & 68 & $67-69$ \\
\hline 15267 & INO 9201 & США & 68 & $67-68$ \\
\hline 15265 & SD 790400 & США & 69 & $68-69$ \\
\hline 15256 & PA 7836-61 & США & 70 & $67-72$ \\
\hline 15258 & PA 7836-2701 & США & 68 & $66-70$ \\
\hline 15090 & MF 9224-164 (г) & США & 70 & $67-73$ \\
\hline 15089 & MF 9224-106 (г) & США & 70 & $67-73$ \\
\hline 15228 & MF 9714-35 & США & 69 & $66-72$ \\
\hline 15033 & PI 244467 & Бразилия & 69 & $68-69$ \\
\hline 14922 & Y 5 & Китай & 69 & $66-73$ \\
\hline 14851 & Numbat & Австралия & 69 & $66-72$ \\
\hline \multicolumn{5}{|c|}{ Ячмень яровой } \\
\hline & Абалак (St) & Тюменская обл. & 70 & $67-74$ \\
\hline 31272 & ДЛ А-14 & Ленинградская обл. & 68 & $67-71$ \\
\hline 30977 & Омский 96 & Омская обл. & 67 & 64-68 \\
\hline \multirow[t]{3}{*}{30895} & Первоцелинник & Оренбургская обл. & 67 & $66-72$ \\
\hline & Танай & Новосибирская обл. & 67 & $63-69$ \\
\hline & Жулдус & Казахстан & 66 & 64-69 \\
\hline 30916 & Pasadena & Германия & 68 & $65-72$ \\
\hline 30943 & Amulet & Чехия & 66 & $64-69$ \\
\hline
\end{tabular}

Большая часть раннеспелых образцов уступала по урожайности стандартным сортам. Особый интерес представляли номера, сочетающие короткий период вегетации с высокой продуктивностью. Выделена группа сортов овса, созревающих на 4-7 суток раньше стандарта (Талисман) и превышающих его по урожайности на 3,8-15,6 \%. Это: Камбулинский (Ленинградская область); КСИ 466/01 (Ульяновская обасть): Новосибирский 2 (Новосибирская область), Vendelin (Словакия) и другие (табл. 2).

Таблица 2 - Источники высокой продуктивности овса с коротким периодом вегетации в условиях Северного Зауралья, 2015-2019 гг.

\begin{tabular}{|c|c|c|c|c|c|c|}
\hline \multirow{2}{*}{$\begin{array}{c}\text { № } \\
\text { каталога } \\
\text { ВИР }\end{array}$} & \multirow[t]{2}{*}{ Сорт } & \multirow{2}{*}{ Страна-оригинатор } & \multicolumn{2}{|c|}{$\begin{array}{c}\text { Период веге- } \\
\text { тации, сут. }\end{array}$} & \multicolumn{2}{|c|}{$\begin{array}{c}\text { Урожайность, } \\
\Gamma / \mathrm{M}^{2}\end{array}$} \\
\hline & & & $\ddot{x}$ & $\mathrm{R}$ & $\ddot{\mathrm{x}}$ & $\mathrm{R}$ \\
\hline & Талисман (St) & Тюменская обл. & 75 & $74-76$ & 470,4 & $409,7-572,0$ \\
\hline 13911 & Камбулинский & Ленинградская обл, & 71 & $69-73$ & 497,0 & $450,0-544,0$ \\
\hline 15319 & Нарпс & Лениградская обл. & 70 & $69-72$ & 488,5 & $445,0-532,0$ \\
\hline 15328 & КСИ 466/01 & Ульяновская обл. & 70 & $68-72$ & 520,5 & $465,0-576,0$ \\
\hline & Новосиборский 2 & Новосибирская обл. & 69 & $68-71$ & 492,6 & $395,0-578,7$ \\
\hline 15191 & Vendelin & Словакия & 68 & $66-71$ & 496,5 & $465,0-528,0$ \\
\hline 14971 & Illinois $62-1535$ & США & 69 & $65-73$ & 478,3 & $436,0-510,0$ \\
\hline 15261 & PA 7836-9938 & США & 68 & $67-69$ & 544,0 & $528,0-560,0$ \\
\hline 14842 & Wandering & Австралия & 71 & $68-73$ & 531,1 & $475,3-570,0$ \\
\hline
\end{tabular}


Среди коллекционных образцов ячменя большой интерес в этом плане представляли: Тандем (Кировская область), Зенит (Тюменская область), Ача (Новосибирская область) (табл. 3).

Таблица 3 - Высокопродуктивные источники скороспелости ячменя ярового в зоне северной лесостепи Тюменской области, 2016-2019 г.

\begin{tabular}{|c|c|c|c|}
\hline Сорт & Происхождение & $\begin{array}{c}\text { Период вегета- } \\
\text { ции, сутки }\end{array}$ & $\begin{array}{c}\text { Урожайность, } \\
\Gamma / \mathrm{M}^{2} \\
\end{array}$ \\
\hline Абалак (St) & Тюменская область & 70 & 626,0 \\
\hline Тандем & Кировская область & 68 & 679,0 \\
\hline Зенит & Тюменская область & 67 & 628,0 \\
\hline Ача & Новосибирская область & 68 & 623,0 \\
\hline
\end{tabular}

В результате проведенных исследований выделены перспективные источники для создания скороспелых сортов овса и ячменя в Северном Зауралье.

\section{Список литературы}

1. Вавилов Н.И. Значение межвидовой и межродовой гибридизации в селекции и эволюции / Н.И. Вавилов // Избр. тр. - М.; Л., 1960. - Т.2. - С. 444-460.

2. Вавилов Н.И. Избранные сочинения. Генетика и селекция / Н.И. Вавилов. - М.: Колос, 1966. - с. 559.

3. Боме А.Я. Изменчивости вегетационного периода и некоторых элементов продуктивности у коллекционных образцов Avena L. в различных условиях среды / Боме А.Я., Лоскутов И.Г., Боме Н.А. // Тр. по прикл. бот., ген. и сел. / Всерос. науч.-ислед. ин-т растениеводства им. Вавилова. - Санкт-Петербург, 2009. - Т.166. - С. 493-498.

4. Сартакова С.В. Испытание коллекции овса в Кемеровской области / С.В. Сартакова, Н.Н. Чуманова, В.Н. Солдатов // Тр. по прикл. бот., ген. и сел. - СПб.: ВИР, 2006. - T. 162. - C. 119-123.

5. Батакова О.Б. Некоторые итоги по изучению длины вегетационного периода в условиях Архангельской области / О.Б. Батакова // Тр. по прикл. бот., ген. и сел. СПб.: ВИР, 2009. Т. 165. - С. 169-173.

6. Смирнова, Л.О. Генетическое разнообразие овса по фотопериодической чувствительности и скороспелости: авореф. дис. канд. биол. наук / Л.О. Смирнова. - С.Петербург, 2011. - 13 с.

7. Заушинцена А.В. Генетические источники для реализации основных направлений селекции ячменя в Сибири / А.В. Заушинцина // Труды по прикл. бот., ген. и сел. СПб.: ВИР, 2011. -Т. 168. - С. 101-104.

8. Методические указания по изучению мировой коллекции ячменя и овса. - Л., 1981. - c. 32 .

9. Методические указания по изучению и сохранению мировой коллекции ячменя и овса. - С-Петербург, 2012. - с. 63.

10. Методика государственного сортоиспытания сельскохозяйственных культур. - М.: Наука, 1989. - с. 194.

11. Доспехов Б.А. Методика полевого опыта. - М.: Колос - 1985. - 381 с.

12. Сорокин О.Д. Прикладная статистика на компьютере / О.Д. Сорокин. - Новосибирск, 2004. - 162 с. 